\title{
Corpus-Assisted Study of Discursive Practices in Russian-language Car Advertisements
}

\author{
L. A. Kochetova \\ Department of English Philology \\ Volgograd State University, VolGU \\ Volgograd, Russia \\ Kochetova@volsu.ru
}

\author{
I. V. Kononova \\ Department of Language Theory and Translation Studies \\ St. Petersburg State University of Economics, SPSUE \\ Saint Petersburg, Russia \\ kafedra_tlt@mail.ru
}

\author{
I. B. Rubert \\ Department of Language Theory and Translation Studies \\ St. Petersburg State University of Economics, SPSUE \\ Saint Petersburg, Russia \\ kafedra_tlt@mail.ru
}

\begin{abstract}
Even though the advertising discourse has been extensively researched, there is a lack of corpus-assisted studies in this field with regard to Russian-language advertising. The paper addresses the gap by using the corpus approach to provide insights into discursive practices in Russian-language car advertisements through investigation of the keywords identified with SketchEngine software tool. The research draws on the corpus of approximately 80,000 words that contains Russianlanguage advertisements available from websites of car dealers in Russia, which is divided into three sub-corpora comprising texts for cars in different price segments. To complete a comparative analysis that would bring out similarities and differences in the advertising strategies and reveal nuances in patterns of meaning, the key word data in each sub-corpus were compared against each other. The results show that lexical choices might be indicative of different discursive practices revealing distinctive sets of cultural values used for pragmatic purposes. Based on a close reading of the advertisements and a search for discursive tendencies, common and specific conceptual metaphors employed in featuring an automobile have been revealed. It was found that though the conceptualization of car rests on similar metaphors across the corpus, they have different entailments and metaphoric interpretation in different price categories.
\end{abstract}

Keywords-corpus linguistics; advertising discourse; discursive practice; conceptual metaphor.

\section{INTRODUCTION}

The study is broadly set within Discourse Theory [1-3], Corpus-Assisted Discourse Analysis [4-6] and Conceptual Metaphor Theory [7] and is aimed at providing insights into automobile advertising discursive practices in the cultural context of modern Russia. Among the numerous definitions of advertising that is traditionally viewed as a public nonpersonal form of communication, the relevant for the purposes of the current research is the one that describes it as brand- initiated communication [8]. Another assumption that underlies the study is that advertising is viewed as being in close relations with culture that is regarded as a broad category of human endeavor and experience, 'an integral part of modern culture' [9]. Complex relations between advertising and culture are best summarized by Whorton who observes that advertising needs culture as a life world, outside its own, to exist [10]. That is, this is in line with the idea stated by Cook who points out that, being most representative forms of discourse advertising foregrounds, there is a need for context when it comes to the full understanding of the overall message - which is the cornerstone of discourse analysis as a method of discursive interpretation [11].

As advertising is extremely sensitive to the cultural context in which it functions, it relies on values in achieving pragmatic goals. Cultural values have been traditionally a subject of the research in international marketing as advertisers are in constant search for strategies that are relevant to expectations and needs of people in a particular culture $[12,13,14]$ whether they are placed in similar cultural contexts, for example, British and American [15, 16] or function in societies that are commonly regarded as distinctive in relation to values shared by discourse community, such as the US and China [17, 18], the US and Japan [19, 20], the US and Arab countries [21], the US and Korea [22]

Given that values are tools used to promote goods and services, one can reasonably hypothesize that adverts for goods of varying social significance would be likely to exercise diverse discursive practices reflected in texts. As language structures acquire a situated meaning in particular contexts, corpus linguistics in this case can identify aspects of those practices, and the analysis of keywords enables one to specifically bring out similarities and differences between them [23]. As brands are important places for gathering values 
[24], insights into pragmatic use of value sets employed by different brands can be gained by analyzing differences between key words data identified in the three sub-corpora.

As representation of experience is reflected in conceptual metaphors, the discussion of adverts is also based on the framework of Conceptual Metaphor Theory of Lakoff's. The analysis is designed to prove that the identified values have a significant increment of meaning in the advertising texts in focus due to conceptualization through metaphor as a mechanism of cognitive-discursive modeling of reality.

Therefore, the purpose of the study is to identify the similarities and differences in advertising techniques between car brands in different price segments. The study relies on key word data analysis in three corpora of advertising materials written in Russian and available from Russian-language websites. Through this analysis, it answers the following research questions: (i) What do the key words reveal about the possible salient patterns of meaning and values they convey? Do they reflect that they are aimed at socially distinct recipients? (ii) What metaphors underlie conceptualization of a car? Do conceptual metaphors vary across the car categories? (iii) What do they reveal about the conceptualization of a car in the cultural context of Russia? This type of approach will help to shed light on the value contents and provide insights into how metaphorical conceptualization of a car differs in discursive practices used for different price segments in the Russian cultural context.

\section{Methodology AND CORPUS DESIGN}

\section{A. Car market in Russia}

The automobile market in Russia is represented by cars of Russian and foreign producers. The statistics provided by the Association of European Businesses (AEB) show that 1.4 million new passenger cars and light commercial vehicles were sold in Russia in 2016, which is $11 \%$ less than in 2015. The best selling cars in Russia are Lada that traditionally occupies the first place with sales figures equal to 266.2 thousand cars, KIA - 149.6, Hyundai - 145.3 thousand and Renault -117.2 . The top three leaders are Avtovaz-RenaultNissan, Hyundai-KIA Group, VW Group. The most popular models were Hyundai Solaris - 90.4 thousand cars, Lada Granta - 87.7 thousand, and KIA Rio - 87.6 thousand. Although the largest media for the distribution of advertising is still television, the Internet advertising showed the impressive $21 \%$ growth, and the share of this media in Russia reached 136 billion rubles. In particular, the performance segment grew by $24 \%$ up to 108.2 billion rubles, and branding reached 27.8 billion rubles.

\section{B. Corpus composition}

The material for this research includes the advertising texts selected by the sampling method from the official Russian websites of world's car manufacturing companies that sold cars in Russia between January 2016 and May 2017. The total number of selected texts is 79 ; the size of texts varies from 96 to 4424 tokens.
The selected texts were divided into three corpora in accordance with the price segment of the Russian automobile market that the advertised cars belong to. The corpus of premium class automobiles comprises the texts taken from the official Russian sites of Mercedes-Benz, BMW, Audi, Porsche (Germany); Bentley, Jaguar, Land Rover (the UK); Lexus, Infiniti (Japan); Volvo (Sweden), Hyundai (South Korea). The medium class corpus includes the advertising materials selected from the Russian sites of BMW, Opel, Volkswagen (Germany); Toyota, Suzuki, Mazda, Subaru, Honda, Mitsubishi, Nissan (Japan); Citroen, Peugeot, Renault (France); Ford (the USA), Kia (South Korea). The economy class automobiles block consists of the texts published on the websites of Chery, Haima, BYD (China); UAZ, AvtoVAZ (Russia); Datsun (Japan), Renault, Chevrolet, Citroen (France); Hyundai, KIA, Daewoo (South Korea); Volkswagen (Germany ); Ford (the USA).

The corpus of premium class automobiles includes 18 advertising texts which comprise 30548 tokens; the medium class automobiles corpus includes 33 texts (29856 tokens), the economy class automobiles block consists of 27 texts (16016 tokens). The ratio of figures characterizing the corpora approximately represents the proportion of the promotional materials devoted to each price segment on the official Russian websites of car manufacturers. Thus, the corpus of the premium class segment, comprising nearly the same number of tokens as the medium segment corpus, includes a much smaller number of texts which suggests that the companies tend to describe their new models of the premium segment in much more details and invest more in advertising of this segment. The ratio of the number of words to the number of texts (showing the average amount of tokens in one advertising text typical of the segment) in the premium class corpus amounts to 1700 , whereas for the medium class corpus it is only 905 . For the economy class segment, this parameter is much lower and equals 593.

The size of the corpus is determined by the materials available from the websites as it covers all popular brands that are on the market and includes the contents of the websites published between January 2016 and May 2017. In this way, the corpus can be viewed as representative and balanced as it reflects discursive practices in contemporary Russianlanguage car advertisements. The composition of the corpus with a list of brands and indicated numbers of tokens per every sub-corpus is presented in Table I. The sub-corpus for economy cars is twice as little in size as compared with other two categories as, on average, texts in this price category have fewer tokens.

\section{Research Design}

Having the goal to compare key words employed in the three corpora and to describe language structures used by companies in car marketing techniques, the authors designed the research as follows. First, the keywords in the three corpora were identified, i.e. the unusually frequent lexical items defined against a reference corpus, which can enable the detection of recurrent patterns of meaning that would otherwise be difficult to access and recognize, especially in a horizontal reading of texts in a corpus $[25,26]$. These were 
TABLE I. THE COMPOSITION OF THE CORPUS WITH A LIST OF BRANDS AND INDICATED NUMBERS OF TOKENS PER EVERY SUB-CORPUS.

\begin{tabular}{|c|c|c|c|}
\hline $\begin{array}{c}\text { Segments } \\
\text { of Russian } \\
\text { Automobile } \\
\text { Market }\end{array}$ & Brands & Models & $\begin{array}{c}\text { Number } \\
\text { of } \\
\text { tokens }\end{array}$ \\
\hline \multirow{19}{*}{$\begin{array}{c}\text { Premium } \\
\text { class } \\
\text { (luxury) } \\
\text { automobiles }\end{array}$} & \multirow{2}{*}{ Chevrolet } & Tahoe & 1227 \\
\hline & & Corvette Z06 & 553 \\
\hline & \multirow[b]{2}{*}{ Mercedes-Benz } & Mercedes-Benz $S$-class & 2884 \\
\hline & & $\begin{array}{l}\text { Mercedes-Maybach } S \text { - } \\
\text { class }\end{array}$ & 2156 \\
\hline & Bentley & Mulsanne Speed & 1699 \\
\hline & Jaguar & Jaguar XF & 2356 \\
\hline & \multirow{3}{*}{$B M W$} & $B M W 4$ & 1250 \\
\hline & & $B M W 7$ & 3326 \\
\hline & & $B M W X 5 M$ & 1910 \\
\hline & Lexus & Lexus GS F & 1266 \\
\hline & \multirow{2}{*}{ Audi } & $A U D I Q 7$ & 143 \\
\hline & & AUDI A8 & 1047 \\
\hline & Volvo & VOLVO XC90 & 606 \\
\hline & $\begin{array}{l}\text { Land Rover } \\
\text { (Jaguar) }\end{array}$ & RANGEROVER & 1760 \\
\hline & Porsche & PORSCHE 718 BOXSTER & 4424 \\
\hline & \multirow{2}{*}{ Infiniti } & INFINITI $Q 70$ & 2126 \\
\hline & & INFINITI QX80 & 1325 \\
\hline & Hyundai & EQUUS & 490 \\
\hline & & TOTAL & 30548 \\
\hline \multirow{34}{*}{$\begin{array}{c}\text { Medium } \\
\text { (middle) } \\
\text { class } \\
\text { automobiles }\end{array}$} & Suzuki & SUZUKI VITARA & 715 \\
\hline & \multirow{3}{*}{ Mazda } & MAZDACX-5 & 586 \\
\hline & & MAZDA3 & 454 \\
\hline & & MAZDA6 & 655 \\
\hline & \multirow{3}{*}{ Škoda } & ŠKODA RAPID & 2397 \\
\hline & & S̆KODA OCTAVIA & 335 \\
\hline & & ŠKODA SUPERB & 933 \\
\hline & Subaru & SUBARU OUTBACK & 2960 \\
\hline & Honda & HONDA $C R-V$ & 1893 \\
\hline & CITROËN & CITROËN C4 PICASSO & 1151 \\
\hline & \multirow{4}{*}{ Toyota } & PRIUS & 1591 \\
\hline & & COROLLA & 255 \\
\hline & & HIGHLANDER & 251 \\
\hline & & $R A V 4$ & 354 \\
\hline & Mitsubishi & PAJERO & 611 \\
\hline & \multirow{4}{*}{ Ford } & FOCUS & 836 \\
\hline & & MONDEO & 484 \\
\hline & & ECOSPORT & 275 \\
\hline & & KUGA & 288 \\
\hline & Peugeot & PEUGEOT 3008 & 1186 \\
\hline & \multirow[b]{2}{*}{ Nissan } & QASHQAI & 194 \\
\hline & & $X-T R A I L$ & 336 \\
\hline & \multirow{2}{*}{ Volkswagen } & JETTA & 296 \\
\hline & & TOUAREG & 1508 \\
\hline & \multirow{4}{*}{ Kia } & SORENTO PRIME & 587 \\
\hline & & SPORTAGE & 323 \\
\hline & & OPTIMA & 303 \\
\hline & & $C E E^{\prime} D G T$ & 212 \\
\hline & Renault & KAPTUR & 857 \\
\hline & $B M W$ & $B M W 1$ & 2251 \\
\hline & \multirow{3}{*}{ Opel } & NSIGNIA & 844 \\
\hline & & MERIVA & 2523 \\
\hline & & ZAFIRA & 1412 \\
\hline & & & 29856 \\
\hline \multirow{5}{*}{$\begin{array}{c}\text { Economy } \\
\text { class } \\
\text { automobiles }\end{array}$} & \multirow{3}{*}{ Daewoo } & GENTRA & 377 \\
\hline & & NEXIA & 339 \\
\hline & & MATIZ BEST & 96 \\
\hline & \multirow{2}{*}{ Chery } & ARRIZO 7 & 202 \\
\hline & & KIMO & 152 \\
\hline
\end{tabular}

TABLE I, CONT.

\begin{tabular}{|c|c|c|}
\hline Datsun & $O N-D O$ & 236 \\
\hline$U A Z$ & PATRIOT & 438 \\
\hline \multirow{3}{*}{$\begin{array}{c}\text { LADA } \\
\text { (AutoVaz) }\end{array}$} & GRANTA & 481 \\
\hline & KALINA & 519 \\
\hline & PRIORA & 427 \\
\hline Haima & HAIMA 7 & 882 \\
\hline$B Y D$ & BYD S6 & 297 \\
\hline \multirow{4}{*}{ Renault } & DUSTER & 161 \\
\hline & SANDERO STEPWAY & 809 \\
\hline & LOGAN & 537 \\
\hline & $M E G A N E$ & 1219 \\
\hline \multirow{5}{*}{ Chevrolet } & LACETTI & 617 \\
\hline & $A V E O$ & 382 \\
\hline & NIVA & 322 \\
\hline & COBALT & 249 \\
\hline & CRUZE & 262 \\
\hline \multirow[t]{2}{*}{ KIA Rio } & RIO & 221 \\
\hline & PiCANTO & 252 \\
\hline \multirow{2}{*}{ Volkswagen } & GOLF PLUS & 2319 \\
\hline & POLO & 466 \\
\hline Ford & FIESTA & 1472 \\
\hline Hyundai & SOLARIS & 1521 \\
\hline CITROËN & $\mathrm{C} 4$ & 761 \\
\hline Tokens & & 16016 \\
\hline
\end{tabular}

identified by SketchEngine software [27] tool that creates and then compares the frequency lists of the two corpora: a reference corpus and a corpus which keywords a researcher wants to find out. The selection of the reference corpus is important as different reference corpora may lead to different lexical items being identified as key in the corpus of interest, thus directly influencing the results. So, the authors compared the corpora of economy cars and medium priced cars against the premium class and then switched the reference corpus in each case. Further, lists of the keywords for the three corpora were compiled and compared against each other. Lexical items related to the automobile description were selected and at the next stage, the key lexical items from the three corpora were categorized along the value perspective. The key words obtained for the three corpora were categorized according to values that they represent, and interpretative analysis of the data was conducted to find out how key lexical items from the list could help to disclose the values that advertisers use in car marketing. At the final stage, linguistic metaphors were analyzed and conceptual metaphors underlying car representation in discourse were revealed. The entailments of these metaphors in different sub-corpora were discussed. 


\section{RESULTS AND DISCUSSIONS}

The key word data obtained for the sub-corpus of premium class cars reveal the following dominant values that are used by advertisers to make claims and persuade the targeted audience. The values represented by key words with Keyness score, indicated in brackets, are given below:

- Choice: «пакет» (package) - 730.5; «конфигурации» (configurations) -253.5 .

- Luxury: «роскошь» (luxury) - 618.2; «роскошный» (luxurious) - 141.3.

- Aesthetics / exquisiteness («цвет» (colour) - 506.2; «кожа» (leather) - 449.9; «вручную» (manually) - 449.9; «дерево» (wood) - 309.6; «ручной» (is used in all the contexts in the word collocation «ручной работы» (handmade) - 225.4; «цветовые» (colour) - 141.3; «оттенки» (shades) - 141.3; «притягивать» (is used in all the contexts in the word collocation «притягивать взгляд» (to catch the eye) - 141.3; «дизайн» (styling) - 8.2.

- Individualism: «эксклюзивность» (exclusivity / uniqueness) - 309.6; «индивидуализация» (individualization) -169.3 .

- Quality: «совершенство» (perfection) - 253.5; «точность» (accuracy) - 225.4; «маневренность» (maneuverability) - 225.4; «быстрый» (fast) - 225.4; «эффективность» (performance) - 197.4; «тщательно» (scrupulously) - 197.4; «мощь» (power) - 169.3; «мгновенно» (instantly) - 141.3; «мастерство» (workmanship) - 141.3).

- Pleasure: «атмосфера» (atmosphere) - 197.4; «ощущения» (sensation) - 141.3.

- Novelty: «инновационный» (innovative) - 169.3.

However, the identified values are not in all the cases represented in the corpus by the keywords (e.g. individualism - «индивидуализация» (individualization)). In many contexts, they are materialised by lexical items that have synonymic or hyper-hyponymic relations with the key language representatives of the values. For example, the word «nакет» (package) occurs in many contexts of the PC as a part of the word combination «nакет опицй» (the package of options), so it has regular paradigmatic connections with the word «опиия», the synonym of the word «выбор» (choice). The similar situation can be observed with the noun «атмосфера» (atmosphere) that represents the value 'pleasure' in the corpus in question due to its regular syntagmatic links with the words of positive evaluation belonging to the lexical-semantic field of 'pleasure'. E.g.: «атмосфера неповторимого уюта» (the atmosphere of unique comfort), «идеальная атмосфера, позволяющая в полной мере насладиться студийным качеством звука» (the ideal atmosphere allowing one to fully enjoy studioquality sound), «расслабляющия атмосфера успокаивающего бриза» (relaxing atmosphere of soothing breeze), etc.

In many contexts of the PC, the identified values are realized in the texts by the words having paradigmatic relations with the keywords nominating the values, i.e. by their synonyms, hypernyms and hyponyms. For example, the word «ощущение» (sensation) represents the value 'pleasure' being the hypernym of the word «удовольствие» (pleasure). The word «инновационный» (innovative) actualizes the value 'novelty' being the contextual synonym of the word «новый» (new).

The comparison of sub-corpus of medium priced cars against the premium class corpus as the reference one allows us to reveal the following values motivating the process of discursive strategies formation in the medium segment advertising:

- Utility («багаж» (luggage) - 434.2; обеспечит (will provide) - 232.0; «компактный» (compact) - 174.3; «вещевые» (is used in all the contexts in the word collocation 'вещевые отсеки' - the storage compartments) - 174.3; «надежная» (reliable) - 174.3; объем (is used in all the contexts in the word collocation «объем багажного отделения» - the luggage compartment volume) - 174.3; «транспортировки» (transportation) - 145.4; «грузы» (cargo) - 10.0; «перевозки» (transportations) - 7.0).

- Novelty («новый» (new) - 323.0; «современные» (modern) - 174.3)

- Comfort: «комфортный» (comfortable) - 232.0; «удобства» (comfort) - 13.0).

- Aesthetics: «яркий» (bright) - 232.0; «стильный» (stylish) - 174.3; «притягивать» (is used in all the contexts in the word collocation «притягивать взгляд» (to catch the eye) -145.4; «аксессуары» (accessories) - 8.0).

- Family: «семья» (family) - 145.4; «семейный» (family's) - 145.4.

- Pleasure: «почувствуете» (feel) - 145.4; «насладитесь» (enjoy) - 145.4.

- Quality («производительность» (performance) - 145.4; «качественный» (quality) - 145.4; «превосходные» (superb) 145.4; «плавность» (is used in all the contexts in the word collocation «плавность хода» - smoothness of movement) 145.4)

Comparing the corpus of economy priced cars against the $\mathrm{PC}$ as the reference corpus, the authors distinguished the following values dominant in the car advertising of this price segment:

- Quality: «улучшенный» (improved) - 322.3; «надежный» (reliable) - 267.8; «надежно» (reliably) - 267.8; «легкость» (is used in all the contexts in the word collocation «легкость в управлении» (ease in driving) - 9.2.

- Comfort: «комфортный» (comfortable) - 322.3; «удобство» (comfort) - 28.1; «климат-контроль» (climate control) -322.3 .

- Novelty: «новая» (new) - 21.8; «современный» (modern) - 7.5.

- Pleasure: «приятный» (pleasant) - 28.1. 
- Aesthetics: «привлекательный» (attractive) - 9.2.

TABLE II. The lexemes with absolute and normalized frequencies in the three analyzed sub-corpora

\begin{tabular}{|l|l|l|}
\hline \multicolumn{4}{|l|}{ Безопасность (safety) the nominative case } \\
\hline & $\mathrm{AF}$ & $\mathrm{NF}$ \\
\hline $\mathrm{PC}$ & 90 & $2,525.04$ \\
\hline $\mathrm{MC}$ & 134 & $3,869.92$ \\
\hline $\mathrm{EC}$ & 119 & $6,372.84$ \\
\hline Безопасности (safety) the genitive case \\
\hline PC & 71 & $1,991.98$ \\
\hline $\mathrm{MC}$ & 90 & $2,599.26$ \\
\hline EC & 89 & $4,766.20$ \\
\hline
\end{tabular}

Comparison of the key word data obtained for each subcorpus makes it possible to draw conclusions about values sets used to achieve the overall communicative goal in the car advertising of each price segment.

Regarding the sets of the identified values, one should point out that the key words corpus analysis allows us to make conclusions only about dominating values in each of the subcorpora. Thus, the value 'safety' is evenly distributed in the corpus so that the words representing this value have the key score below the threshold value defined as equal to 6.83 . Table II shows lexemes representing this value with absolute and normalized frequencies in the three analyzed sub-corpora.

The dominant values that set apart the PC sub-corpus from the other two are those of 'Choice', 'Luxury' and 'Individualism'. Each of these values evokes associations with the social status concept, which is inherent in the advertising discourse of the Premium class segment. It should be also mentioned that even if a certain value reveals its presence in all the three corpora, its lexical materialisation may be found in semantically different lexical items in each sub-corpus. Thus, the value 'Aesthetics' is common in all the three subcorpora, but in premium class cars advertising it is represented by such semantic signs as 'exquisiteness', 'exclusivity', 'the refinement of taste', whereas being a part of the semantic structure of the medium class cars advertising it contains the semantic signs 'brightness' and 'style'. As the values of 'Utility' and 'Family' are characteristic of the medium price segment, the value opposition Individualism - Family is observed between the sub-corpora of the premium and medium classes.

The idea of the high social status and superiority in the premium class sub-corpus is supported by the considerable number of foreign (English) words among those with the high key score. All of them are names of options offered by the car manufacturers or technical words: AMG - 730.5, V - 590.2, Individual - 478.0, Executive - 393.8, Drive - 365.7, Lounge - 309.6, Touch - 197.4, PRE-SAFE - 197.4, ADAPTIVE 197.4, iDrive - 169.3. The intentional avoidance of the translation of English words in the advertising is part of the discursive strategy aiming at creating the idea of undoubted awareness of the addressee of the advertising texts about the latest technical innovations in the field of car-manufacturing and, consequently, at implying the idea of their high social status.
To answer the last research question, manual analysis of texts was performed with the purpose to reveal how an automobile is conceptualized in the Russian-language advertising texts and what entailments can be inferred. The analysis shows that the premium car corpus contains the conceptual metaphor 'an AUTOMOBILE is a HUMAN BEING'. This traditional conceptual metaphor has the following important entailments in the PC sub-corpus:

- A car design is appearance.

- Car details are facial features.

- Parts of a car are parts of a human body.

- Car features are character traits.

Thus, linguistic data show that the word collocation «внешний вид» (appearance) forms combinations with the following adjectives in the attributive function: «респектабельный» (respectable) - 12.19, «мужественный» (manly) - 11.54, «атлетичный» (athletic) - 11.54, «солидный» (reputable) - 11.54, «неотразимый» (charming) - 11.54. The gender perspective on anthropomorphic metaphoric conceptualisation of an automobile in this price segment shows that it is male-oriented as luxury class cars are assigned such exterior masculine characteristics as physical strength, brutality, athleticism, e.g., «Corvette Z06. Рожденный на треке. Брутальный, впечатляющий, мощчный» (Born on the track. Brutal, impressive, powerful). «Легендарный внедорожник ChevroletTahoe - это тщательно продуманный дизайн с изящными скульптурными обводами и брутальными атлетическими контурами» (The legendary ChevroletTahoe has meticulously elaborated design with sleek, sculptural lines and brutal athletic contours). «Четкие линии удлиненного капота подчеркивают классическую, и вместе с тем, инновационную атлетичность нового ВMW 4 серии Купе» (Clear lines of the long hood accentuate the classic, yet, innovative athleticism of the new BMW 4 series Coupé). «Эффектные линии и “мускулистые” поверхности нового кабриолета С-Класса служат подтверждением этого завораживающего дух стиля» (The impressive lines and 'muscular' surface of the new $\mathrm{C}$ class cabriolet is the testimony to this bewitching style). «Задние фонари гармонично вписываются в общую концепцию и подчеркивают атлетичную иирину BMW 4 серии Купе» (The rear lights blend harmoniously with the overall concept and highlight the athletic width of the BMW 4 series Coupé).

As text fragments demonstrate the impressive car, dimensions are conceptualized through assimilating its front part to a part of a human body, namely, broad male shoulders: the collocation 'атлетическая ширина' (athletic width) regularly collocates with the noun плечи (shoulders).

The common metaphor that conceptualizes the car as a human being is realized in the pattern "ENGINE is a HEART" in the following contexts: «Сердце нового Tahoe высокоэффективный двигатель...» (The heart of the new Tahoe is a high-efficiency engine...); «Сердце нового MulsanneSpeed - собранный вручную двигатель V8» (The heart of the new MulsanneSpeed is a hand-built V8 engine). It 
is commonly the case that car features are facial features as it is shown in the following text fragment: «Дизайн нового кабриолета даёт новую интерпретацию идее современной роскоши, добавляя к ней нотку молодости и массу благородных деталей» (The design of the new cabriolet gives a new interpretation of the idea of modern luxury by adding to it a touch of youth and a lot of noble details).

Car features are conceptualized in terms of character traits as it is inferred from the data below: «...есть также целый ряд эксклюзивных деталей оснащения, подчёркивающих лидерские амбиции Mercedes-Maybach S-Класса» (...there are also a number of exclusive parts, emphasizing the leadership ambitions of Mercedes-Maybach S-Class); "MulsanneSpeed. «Непревзойденная харизма» (Incredible charisma); «Экстерьер: волнующая спортивность и хладнокровная верность стилю» (Exterior: exciting coldblooded sportiness and fidelity to style); «Высокодинамичные автомобили AMG - это завораживающая сила в чистом виде» (High-performance cars AMG - is a fascinating power in its purest form); «Заметно, что его облик стал еще более решительныл...» («It is noticeable that its appearance has become even more resolute ...»).

The entailments of the conceptual metaphor 'an AUTOMOBILE is a HUMAN BEING' form the basis for its interpretation. As it was demonstrated, metaphoric transfer in the texts, featuring premium class cars, is based on the similarity of emotional impact caused by a vehicle and an impression produced by a human being that possesses certain socially appreciated qualities and features. Metaphorical conceptualization serves to assimilate superb technical characteristics or design features of a vehicle to highly approved character traits such as nobility, charisma, vitality, leadership qualities, ambitiousness, power of spirit, composure, and conveys the idea that the car matches the image of a spiritually and physically strong male.

In the sub-corpus of medium-price cars, the conceptual metaphor 'an AUTOMOBILE is a HUMAN BEING' has entailments:

- Car technical properties are person's behaviour.

- Car features are character traits.

The analysis shows that in the sub-corpus under study, these metaphors are formed by the noun «характер» (character) that collocates with evaluative adjectives in the attributive position: «сильный» (strong) - 11.09, «яркий» (bright) - 11.54, «эксцентричный» (eccentric) - 10.35, «напористый» (pushy) - 10.30 , «незаурядный» (remarkable) - 10.30, «независимый» (independent), «уверенный» (confident) - 10.04, «динамичный» (dynamic) - 9.75; the noun «образ» (image) that is used in attributive collocations with the adjectives «решительный» (determined) - 11.30, «динамичный» (dynamic) - 10.35, «активный» (active) - 10.00.

The metaphor-based images are based on the lexical items accentuating character traits and person's behaviour that are gender neutral and can be easily associated with either sex.
E.g.: «Колеса, доступные в любой комплектации, выглядят броско, дерзко и современно, подчеркивая эксиентричный характер модели». («Тhe wheels are available in any configuration, look flashy, bold and contemporary, highlighting the eccentric nature of the model»).

The data show that a conceptual metaphor that is clearly identified in the sub-corpus of medium-class cars is the one that conceptualizes an automobile in terms of animals. Within the category of animals, the metaphoric conceptualization can rest on the notion 'an AUTOMOBILE is a PREDATOR' that has the following entailments in the discourse in focus:

- A Car maneuverability is a predator's agility.

- A Car technical perfection is a predator's physical strength.

The conceptual metaphor 'An AUTOMOBILE is an ANIMAL' is realized, for instance, in the following contexts: «За счёт массивной решётки радиатора, прищуренных фар и скошенной задней части кузова формируется образ хищника, готового в любую секунду доказать своё превосходство». («Due to the massive grille, narrowed headlights and a sloping rear part of the body, the image of a predator ready at any moment to prove its superiority is formed»); «Мы постарались привить автомобилю характер гепарда - одного из самых быстрых и ловких хищников на Земле». («We have tried to impart to the vehicle the character of a Cheetah - one of the fastest and cleverest predators on Earth»); «...кузов Mazda 6 изобилует экспрессивными линиями, передающими силу и динамику одного из самых грациозных хищников на Земле - гепарда» («...the body of the Mazda 6 is replete with expressive lines to convey the power and momentum of one of the most graceful predators on Earth - the Cheetah»). Due to the assimilation of a car to a predatory animal, this conceptual metaphor highlights such qualities of a vehicle as its maneuverability, speed and power.

In some contexts, however, the zoomorphic conceptual metaphor assimilates a medium class car to a domestic animal (a horse or a mule) with the following important entailments:

- A Car durability is a domestic animal's endurance.

- A Car utility is domestic animal's benefits in household and farming.

- A Car reliability is a domestic animal's devotion to its master.

The car is conceptualized a companion, a friend as well as a helper that takes on certain burdens and facilitates the life of its owner. For example, «Вера в силь и выносливость такого помощника вселяет уверенность, позволяет открывать новые маршруты, штурмовать преграды, брать любые препятствия». («Faith in the strength and endurance of such helper inspires confidence, allows one to open new routes, storm the barriers, overcome any obstacle»); «Toyota Highlander. Обладатель огромной сильь вызывает неподдельное уважение». («The owner of enormous power evokes genuine respect»). The texts emphasize such car qualities as reliability in operation, durability, household use, 
thus contributing to the discursive actualisation of the values 'Family' and 'Utility'.

Perspective on the EC category showed that discursive practices do not favour the metaphoric style as compared to the discourse of the Premium and Medium cars advertising. Linguistic metaphors are used occasionally and they are not based on regularly reproducible conceptual models.

\section{CONCLUSION}

To summarize, the corpus-assisted analysis shows differences in advertising discursive practices used in Russianlanguage car adverts. In value perspective, the advertisements in the status of PC sub-corpora project are far more valuable than texts from the other two categories, and present exaggerated male-oriented status claims. Meanwhile, the category of medium-priced cars is characterized by a more pragmatic profile where the themes of particular importance are family relations and utilitarian car features that are viewed as oppositions to representations of highest levels of social standing. The texts in the economy class category do not present any category-specific patterns. Advertisers echo values from the medium price category and emphasize the idea that economy class cars are not inferior to more expensive brands.

All the three price categories are rather locked in patterns of the automobile conceptualization as they present very similar profiles that rest on the common conceptual metaphor 'an AUTOMOBILE is a HUMAN BEING'. No gross differences are observed across the three sub-corpora except that the gender perspective in the premium car advertising texts is based on the lexical units that induce similarity between a luxury automobile and a physically and spiritually strong male. The image created in car adverts of the medium price category is much less gender-specific as it emphasizes character traits that are much less closely associated with either sex. However, adverts of medium-price cars are based on the 'an AUTOMOBILE is an ANIMAL' metaphor that entails the perception of a car as a helper, a friend and a carrier, the patterns that are conspicuously absent in other categories. The texts in the economy class category are least likely to engage with metaphorical patterns and rely on a more informative and laconic style.

The limitation of the study is that it examines advertising on websites and excludes other channels of communication, thus making cross-media comparisons a purpose for future research. Another restriction is that no experimental methodologies were designed to ask consumers to report their perceptions of cars presented in the advertising texts under investigation. Finally, the study is of interest to advertising practitioners who are interested in better understanding of perspectives in marketing strategies.

\section{Acknowledgment}

The research for this study was funded by the Russian Foundation for Fundamental Studies (RFFI), grant 15-0400134 'Historical Discourse Studies: Issues, Methodology and Prospects'.

\section{References}

[1] G R. Wodak, "What CDA is about: a summary of its history, important concepts and its developments," Methods of Critical Discourse Analysis, R. Wodak and M. Meyer, Eds, 2nd ed. London: Sage, 2009, pp. 1-13.

[2] N. Fairclough, Discourse and Social Change. Cambridge: Polity Press, 1992.

[3] J.P. Gee, How to do Discourse Analysis: A Toolkit. New York: Routledge, 2011.

[4] P. Baker, Using Corpora in Discourse Analysis. London \& New York: Continuum, 2006.

[5] P. Baker, Using Corpora in Discourse Analysis. London: Continuum, 2008.

[6] A. Partington, "Modern diachronic corpus-assisted discourse studies on UK newspapers: an overview of the project," Corpora, vol. 5, iss. 2, pp. 83-108, 2010.

[7] G. Lakoff, M. Johnson, Metaphors We Live by. Chicago: The University of Chicago Press, 1980.

[8] M. Dahlen and S. Rosenberg, "If advertising won't die, what will it be? Toward a working definition for advertising," Journal Of Advertising, vol. 45, iss. 3, pp. 334-345, 2016.

[9] W. Leiss, , S. Kline, S. Jhally, Social Communication in Advertising: Persons, Products \& Images of Well-being. Toronto ; New York : Methuen, 1986.

[10] C. Whorton, Advertising as Culture. Intellect Bristol, UK, 2013.

[11] G. Cook, The discourse of advertising. 2nd edition. Interface. London, UK: Routledge, 2001.

[12] R. Goldman, Reading Ads Socially. London: Routledge, 1992.

[13] W. M. O'Barr, Culture and the Ad: Exploring Otherness in the World of Advertising. Boulder, Colo : Westview Press, 1994.

[14] Y. Zhang, "Going East: A historical content analysis of cultural values and symbols in advertising themes and tactics of early 20th century foreign advertising in China". Paper presented at the annual meeting of the International Communication Association, Sheraton New York, New York City, NY, 2008. Retrieved from: http://www.allacademic.com/meta/p11747_index.html.

[15] Z. Caillat and B. Mueller, "Observations: the influence of culture on American and British advertising: an exploratory comparison of beer advertising," Journal of Advertising Research, vol. 36, iss. 3, pp.79-88, 1996.

[16] S. Dahl, Cultural values in beer advertising in the UK, the Netherland and Germany. Presented at the Research Day, Intercultural Discourse Group. Luton: University of Luton, 2000.

[17] H. Cheng and J.C. Schweitzer, "Cultural values reflected in Chinese and U.S. television commercials," Journal of Advertising Research, vol. 36, iss.5, pp. 27-45, 1996.

[18] C. A. Lin, "Cultural values reflected in Chinese and American television advertising", Journal of Advertising, vol. 30, iss. 4, pp. 83-94, 2001.

[19] B. Mueller, "Reflections of culture: An analysis of Japanese and American advertising appeals," Journal of Advertising Research, vol. 27, pp. 51-59, 1987.

[20] S. Okazaki, B. Mueller, C.Taylor,"Global consumer culture positioning: testing perceptions of soft-sell and hard-sell advertising appeals between US and Japanese consumers", Journal of International Marketing, vol. 18 , iss. 2, pp.20-34, 2010.

[21] M. Kalliny, L. Gentry, "Cultural values reflected in Arab and American television advertising," Journal of Current Issues and Research in Advertising, vol. 29, iss.1, pp. 15-32, 2007.

[22] A. S. Young, A. Hongmin, S. Yongjun, "Cultural values in financial services advertising: a cross-cultural study of magazine ads in the USA and Korea", Journal of Services Marketing, iss.5, pp. 349-360, 2014.

[23] M. Handford, "Professional communication and corpus linguistics." in Hyland, K., Huat, C. M. and Handford, M. eds, Corpus Applications in Applied Linguistics. London and New York: Continuum International Publishing Group. 13-29.

[24] B. Richards, I. MacRury, J. Botterill, The dynamics of advertising. New York, London, Routledge, 2000. 
[25] M. Scot, "PC analysis of key words - and key key words", System vol. 25 , iss.2, pp. 233-245, 1997.

[27] https://www.sketchengine.co.uk/

[26] M. Stubbs, "Three concepts of keywords" in: Bondi, M. and Scott, M. eds Keyness in Texts. Amsterdam: John Benjamins, pp. 21-42, 2010. 